\title{
Can small pelagic fish landings be used as predictors of high-frequency oceanographic fluctuations in the 1-2 El Niño region?
}

\author{
Franklin Isaac Ormaza-González ${ }^{1}$, Alejandra Mora-Cervetto ${ }^{2}$, Raquel María Bermúdez-Martínez ${ }^{2}$, Mario \\ Armando Hurtado-Domínguez ${ }^{3}$, Manuel Raúl Peralta-Bravo ${ }^{3}$, and Viviana Mariuxi Jurado-Maldonado ${ }^{3}$ \\ ${ }^{1}$ Escuela Superior Politécnica del Litoral, Vía Perimetral km 30.5, Guayaquil, Ecuador \\ ${ }^{2}$ Universidad Espíritu Santo, Vía Samborondon km 2.5, Samborondon, Ecuador \\ ${ }^{3}$ Instituto Nacional de Pesca del Ecuador, Letamendi 102 y la Ría, Guayaquil, Ecuador
}

Correspondence to: Franklin Isaac Ormaza-González (formaza@espol.edu.ec)

Received: 30 March 2016 - Revised: 26 July 2016 - Accepted: 27 July 2016 - Published: 25 August 2016

\begin{abstract}
A group of small pelagic fish captured between 1981 and 2012 within El Niño area 1-2 by the Ecuadorian fleet was correlated with the oceanographic Multivariate ENSO Index (MEI), and the Oceanographic El Niño Index (ONI) referred to El Niño region 3-4. For the period 19812012, total landings correlated poorly with the indexes, but during 2000-2012 (cold PDO) they proved to have a 14$29 \%$ association with both indexes; the negative slope of the curves suggested higher landing during cold events (La Niña) and also indicated a tendency to decrease at extreme values ( $>0.5$ and $<-1.0$ ). Round herring (Etrumeus teres) fourthquarter $\left(\mathrm{Q}_{4}\right)$ landings were related to the MEI in a nonlinear analysis by up to $80 \%$. During moderate or strong $\mathrm{La}$ Niña events landings noticeably increased. Bullet tuna (Auxis spp.) catches showed a negative gradient from cold to warm episodes with an $R^{2}$ of 0.149 . For Chilean jack mackerel (Trachurus murphyi) irregular landings between 2003 and 2007 were observed and were poorly correlated $\left(R^{2}<0.1\right)$ with ONI or MEI. Anchovy (Engraulis ringens) captured in Ecuadorian waters since 2000 had an $R^{2}$ of 0.302 and 0.156 for MEI and ONI, respectively, but showed a higher correlation with the cold Pacific Decadal Oscillation (PDO). South American pilchard (Sardinops sagax) was higher than -0.5 for the ONI and MEI, and landings dramatically decreased; however, $\mathrm{Q}_{4}$ landings correlated with $\mathrm{ONI}$ and MEI, with $R^{2}$ of 0.109 and 0.225 , respectively $(n=3)$. Linear correlation of $\mathrm{Q}_{4}$ indexes against the following year's $\mathrm{Q}_{1}$ landings had a linkage of up to $22 \%$; this species could therefore be considered a predictor of El Niño. Chub mackerel (Scomber japon-
\end{abstract}

icus) landings did not have a significant linear correlation with the indexes for 1981-2012 and therefore could not be considered a valid predictor. Chuhueco (Cetengraulis mysticetus) is a local species with high landings during El Niño years and, conversely, remarkably low landings during La Niña years. Additionally, chuhueco availability and landings were negatively affected by cold PDOs. Pacific thread herring (Opisthonema spp.) showed a 24 and $36 \%$ relationship between landings $\left(\mathrm{Q}_{1}\right)$ and the MEI and ONI $\left(\mathrm{Q}_{4}\right)$. Therefore, results suggest that the South American pilchard and Pacific thread herring could be considered good species to use as predictors of El Niño in region 1-2 (Ecuador), especially when average $\mathrm{Q}_{4} \mathrm{MEI} / \mathrm{ONI}$ is used against the next trimester $\mathrm{Q}_{1}$ landing. All species were prone to lower landings and/or fishing availability during strong-extreme events (ONI/MEI, $>1.0$ and $<-1.0$ ), and were also shown to be affected by the PDO. In the long term, landings decreased under warm PDO and vice versa, and therefore PDO fluctuations could be used to help manage these fisheries and to help the industry in long-term planning.

\section{Introduction}

Oceanographic events of high and low frequencies such as El Niño and La Niña and Pacific Decadal Oscillation (PDO) have been studied for some decades, generating a huge amount of research literature (e.g., Wirtky, 1965; McPhaden, 1993, 1999; Trenberth, 1997; Clarke, 2008; Khider et al., 
2011), a vast number of webpages (see, e.g., NOAA), longperiod projects (e.g., TAO-TRITON), more than 20 statistical and dynamics prediction models (ENSO-NOAA) and dozens of institutions and laboratories with hundreds of marine scientists (Ormaza-González et al., 2014a).

Apart from physical impacts, there are also chemical and biological variations in the ocean. The impact data and/or information on the chemistry of the ocean due to these events are scarce; a few reports indicate that dissolved oxygen, nitrate and phosphate and salinity in the water column and surface during a cold event (La Niña, 1996) followed up by a warm one (El Niño, 1997-1998) were higher in 1996 than 1997-1998 (Sievers and Vega, 2000). Additionally, during El Niño the water bodies from Panama Bay move south; these have thermal anomalies as high as $6{ }^{\circ} \mathrm{C}$ (surface temperature $>27^{\circ} \mathrm{C}$, e.g., Trenberth, 1997), lower salinity (around $32 \mathrm{psu}, \mathrm{D}^{\prime} \mathrm{Croz}$ et al., 1991), nutrient concentration much lower and primary production productivity (Chávez et al., 2003), which in turn affects higher trophic levels (Ormaza-González et al., 2014a, b). Conversely, during La Niña occurrence, the Humboldt and Cromwell currents emerge at the surface in front of Ecuador and Peru, bringing cold and nutrient-rich waters that cause primary production to increase, so energy is transferred to higher levels of the trophic chain. Changes in water temperature, both higher and lower, may cause a redistribution of fish in the sea, making those less available for capture by fisheries; furthermore, these changes generate modifications to fish growth, survival and reproduction rates (affecting biological attributes such as size and weight). One earlier work of Barber and Chávez $(1983,1986)$ reported changes in primary production during these events due to variations of nutrients, which transit for high (La Niña) to low (El Niño) concentrations. Iriarte and González (2004) found a variation from $80 \mathrm{mg} \mathrm{m}^{-3}$ under normal conditions to $5 \mathrm{mg} \mathrm{m}^{-3}$ during and after El Niño as well as the presence of different species of phytoplankton, and changes from diatoms to nano- and pico-plankton. Gaxiola-Castro et al. (2010) reported the magnitude of affection to the pelagic system in the waters of Baja California, demonstrating that a good relationship between chlorophyll concentration and sardine (Strangomera betincki) abundance was found during lowand high-frequency periods in Chile $\left(34-40^{\circ} \mathrm{S}\right.$; Gómez et al., 2012). In addition, Aburto-Oropeza et al. (2007) detected a decrease in macro-algae Sargassum sp., while the Multivariate ENSO Index (MEI) increased. Sardine and horse mackerel exposed to El Niño conditions had their weight modified: sardines decreased from 19.3 to $9.86 \%$ and mackerel increased by $1.32 \%$ (Dioses, 1983). Changes in the stomach content of anchovies, round sardine (Etrumeus teres), have been reported by Sánchez de Benites (1983), demonstrating that El Niño, in fact, modifies nurturing in pelagic species. De la Cuadra (2010) has found a strong relationship between the high- and low-frequency events with small pelagic-like round sardine, Chilean jack mackerel (Trachurus murphyi),
South American pilchard (Sardinops sagax) and others using sea surface temperature (SST) anomalies in the region between the Ecuador coast and the Galapagos Islands.

Low-frequency events - PDO - were first reported and named by Mantua et al. (1997) in a paper about Alaskan salmon (Oncorhynchus sp.). The PDOs are warm and cold periods of around 20 and 25-30 years; the latest warm PDO spanned from 1977 to 1999 , and the present cold period will go from 2000 to around 2025/2030. A recent paper summarizes and provides good insight into the PDO (Mantua and Hare, 2000). More recently, Hsieh et al. (2009) studied 34 dominant species in larval state in Baja California using 50-year series in which superficial and sub-superficial $(200 \mathrm{~m})$ water temperature varied, finding that species had changed geographical distribution from cold to warm periods and noticing the abundance of 25 more taxa during cold periods; even species like the salpas (Salpa maxima, Pegea socia, Cyclosalpa bakeri, and Cyclosalpa affinis) are influenced by the PDOs. Lavaniegos and Ohman (2003) determined the presence of these species in the cold period between 1951 and 1976, an absence from 1981 to 1999 as a result of the warm PDO, and finally a return in 2000, considered the beginning of the present cold period. Important commercial fisheries like tuna are also impacted by these events in diverse manners: distribution, reproduction, recruitment and growth rate (e.g., Lehodey et al., 1997, 1998, 2003, 2006; Lehodey, 2004). Considering one of the most abundant and important small pelagic species, anchovy (Engraulis ringens), it was found that the fluctuation between warm and cold periods (every 10 years) determines the sequence of replacement anchovy-sardine-anchovy corresponding to cold-warm-cold periods (Yáñez et al., 2008; RodríguezSánchez et al., 2001). Concurrently, according to Ñiquen and Bouchon (2004), prior to a warm event, a mono-species habitat is found, and, after its occurrence, a multi-species habitat is established. Warm events have negative impacts on the biomass, size, recruitment and distribution (Cahuin et al., 2013) of some species but positively affect species like sardine (Sardinops sagax), mackerel (Trachurus murphyi), pacific mackerel (Scomber japonicus) and long-nose anchovy (Anchoa nasus). Sánchez-Velasco et al. (2000) reported similar results with anchovy (Engraulis mordax), which was absent during El Niño 1997-1998 but became abundant after it ended. Dioses (1983) found a drop in corporal weight of sardine (Sardinops sagax), jurel (Trachurus murphyi) and caballa (Scomber japonicus peruanus) during El Niño in the Peruvian sea in 1982-1983 in comparison to normal conditions (1981).

The present work attempts to elucidate whether it is possible to use small pelagic landings as a sort of predictor to determine the presence or not of high-frequency events (El Niño and La Niña) on the Ecuadorian coast (area 1-2, Fig. 1) when they are declared by indexes like the Oceanographic El Niño Index (ONI) and Multivariate ENSO Index (MEI) 


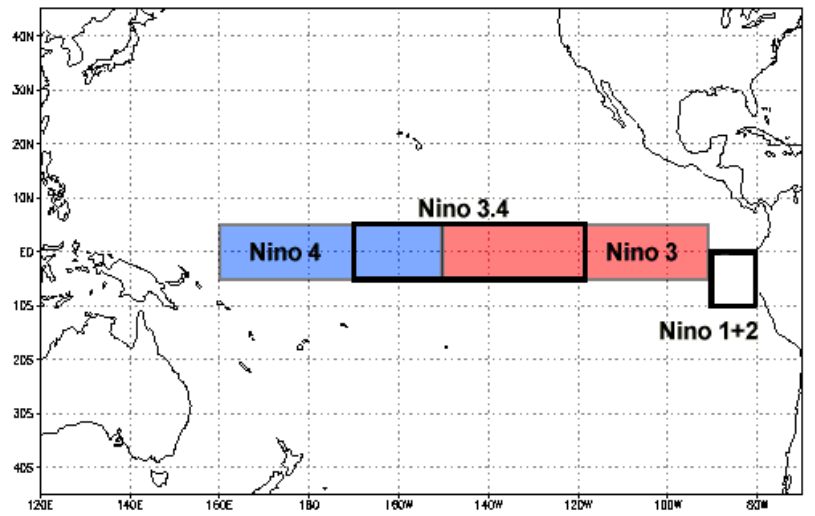

Figure 1. The regions of El Niño (NOAA 1, http://www1.ncdc. noaa.gov).

in area 3-4 (Fig. 1). Also, the impacts of the low-frequency events (PDO) on these landings are examined.

\section{Material and methods}

The ONI and MEI are oceanographic indexes presently accepted as establishing whether El Niño or La Niña is occurring or not. The ONI (Smith et al., 2008; Null, 2013) is based on SST anomalies in the so-called El Niño 34 region (Fig. 1) that is delimited by $5^{\circ} \mathrm{N}-5^{\circ} \mathrm{S}, 120$ $170^{\circ} \mathrm{W}$; on the other hand, the MEI (Wolter and Timlin, 1998, 2011) is a multivariable index (SST, zonal and meridional components of surface winds, total cloudiness fraction of the sky, surface air temperature and sea-level pressure) in the same El Niño region; both indexes are available from http://www.cpc.ncep.noaa.gov/products/analysis_ monitoring/ensostuff/ensoyears.shtml and http://www.esrl. noaa.gov/psd/enso/mei/, respectively. The data series from 1981 to 2012 was yearly averaged.

Annual landings of round herring (Etrumeus teres), chilean jack mackerel (Trachurus murphyi), bullet tuna (Auxis thazard or spp.), anchovy (Engraulis ringens), South American pilchard (Sardinops sagax), chub mackerel (Scomber japonicus), chuhueco (Cetengraulis mysticetus), and pacific thread herring (Opisthonema spp.) have been monitored and registered on a monthly basis by the National Institute of Fisheries (INP) of Ecuador since 1981; catching effort, measurement of size, length, weight, sexual genera and other biological parameters have also been recorded. The monitoring also includes fleet classification and active or inactive fishing boats during the month sampled. These data were provided by the INP and are obtained in order to manage the fisheries. The activities of the fleet are mainly coastal with limited freezing or refrigerating chambers, so fishermen go for 1 working day and the catch is immediately used by canneries or fish meal plants upon landing. The temporal series 1981-2012 was analyzed first, species by species; second, due to the fact that this series included both warm (1977-1999) and cool (2000-present) PDO, they were split into two series, namely, 1981-1999 and 2000-2012. The indexes were taken as independent variables, and the landings and other biological data as dependent ones in order to correlate them in time. The time was on a yearly and/or quarterly basis: Q 1 (January-March), Q 2 (April-June), Q 3 (JulySeptember) and $\mathrm{Q}_{4}$ (October-December). Statistical linear and polynomial (up to $n=6$ ) regressions were used.

\section{Results}

As a response to variable-frequency oceanographic fluctuations, pelagic species change their distribution, which in turn affects fish availability for capture, thus ultimately impacting on landings. Results are presented for eight species whose landings were examined in time and against the indexes ONI and MEI from 1981 until 2012; the series was split into 1981-1999 (warm PDO) and 2000-21012 (cold PDO).

A historical maximum landing was observed in 1985 after the 1982 El Niño. From this point, volume captured decreased consistently until 1990, and from then on it remained at about 190000 metric ton (mt, except for peaks in 19951997). In general terms, fisheries registered a constant fall for total and individual species landings (Fig. 2).

When correlating total landings (1981-2012) against the ONI and MEI, linear regression was poor $\left(R^{2}<0.01\right.$, Fig. 3a), but using polynomial regression $(n=5)$ an $R^{2}$ of 0.171 and 0.149 (Fig. 3b) was obtained for the ONI and MEI, respectively. Most landings were registered between values from -0.5 to 0.5 of both indexes, showing that the highest registered peak was when the indexes were around -0.5 , indicating that under cold conditions (La Niña) there was higher availability for fishing (Fig. 2). The slope for the linear regression was negative, suggesting there was more available biomass under moderate negative anomalies; also, the curves suggest that under extreme events, cold or warm, capture tends to decrease (Fig. 3b, c, d), as fish move to less stressful water masses.

For the period 2000-2012, which corresponds to a cold PDO (Fig. 3d), the linear regression rendered $R^{2}$ values of 0.143 (MEI) and 0.291 (ONI), which are higher when the correlation is executed in the period 1981-2012; also, the negative slope of the curve indicates consistency with what is said above. Linear regression indicates around 14-29\% direct dependence on or association of landing with these indexes; likewise, the slope of the curve was negative in the whole analysis period, reaffirming the fact that there is less biomass under warm conditions.

This exercise also would suggest that statistical analysis in the continuous series is affected by the change from a warm to a cold PDO, as the complete period includes both interdecadal periods and the remnant noise for a period affects the next one. 


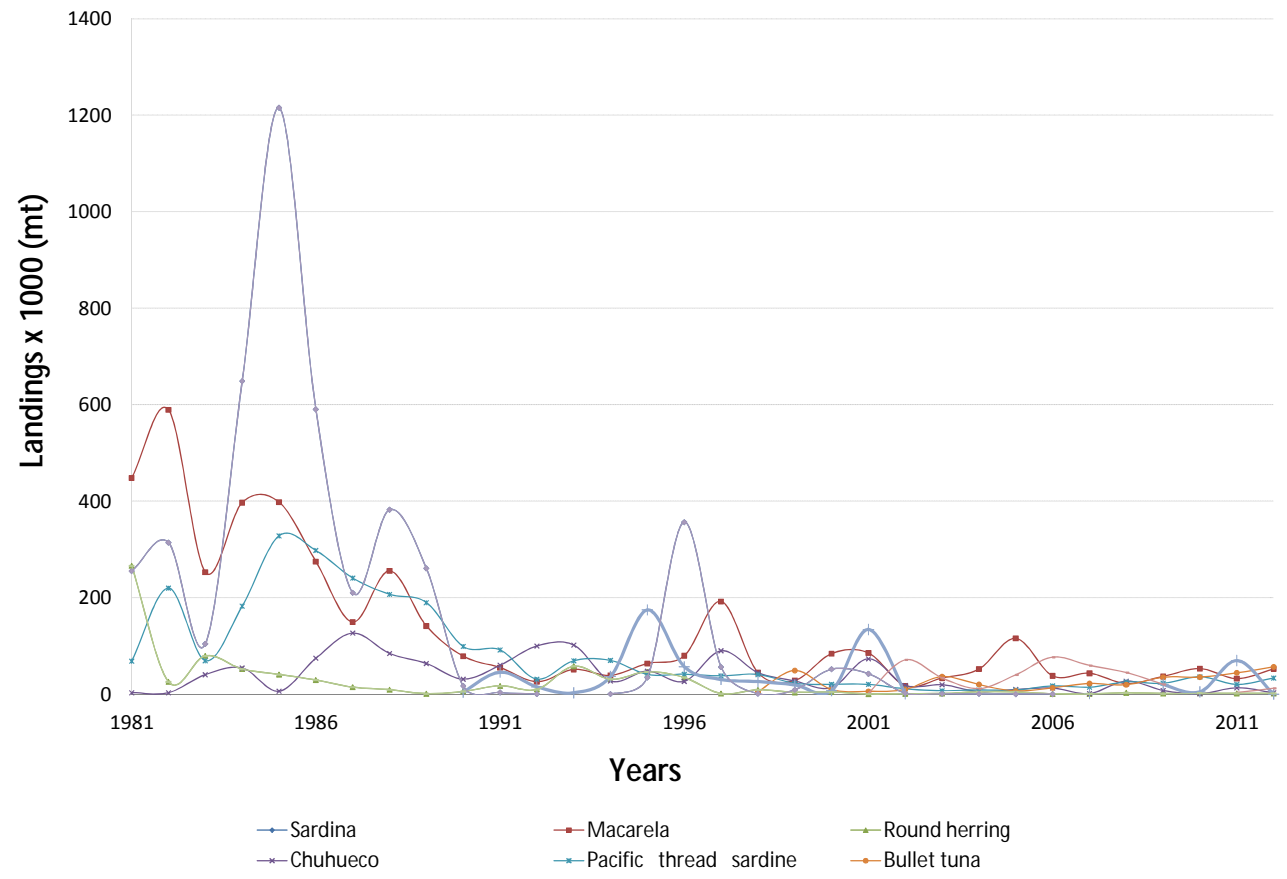

Figure 2. Total landings of pelagic fish (1981-2012) registered by the Ecuadorian fleet. Sardine (sardinas), chub mackerel (macarela), round sardine (sardina redonda), Pacific thread sardine (pinchagua), bullet tuna (botella), Chilean jack mackerel (jurel), and anchovy (anchoveta).
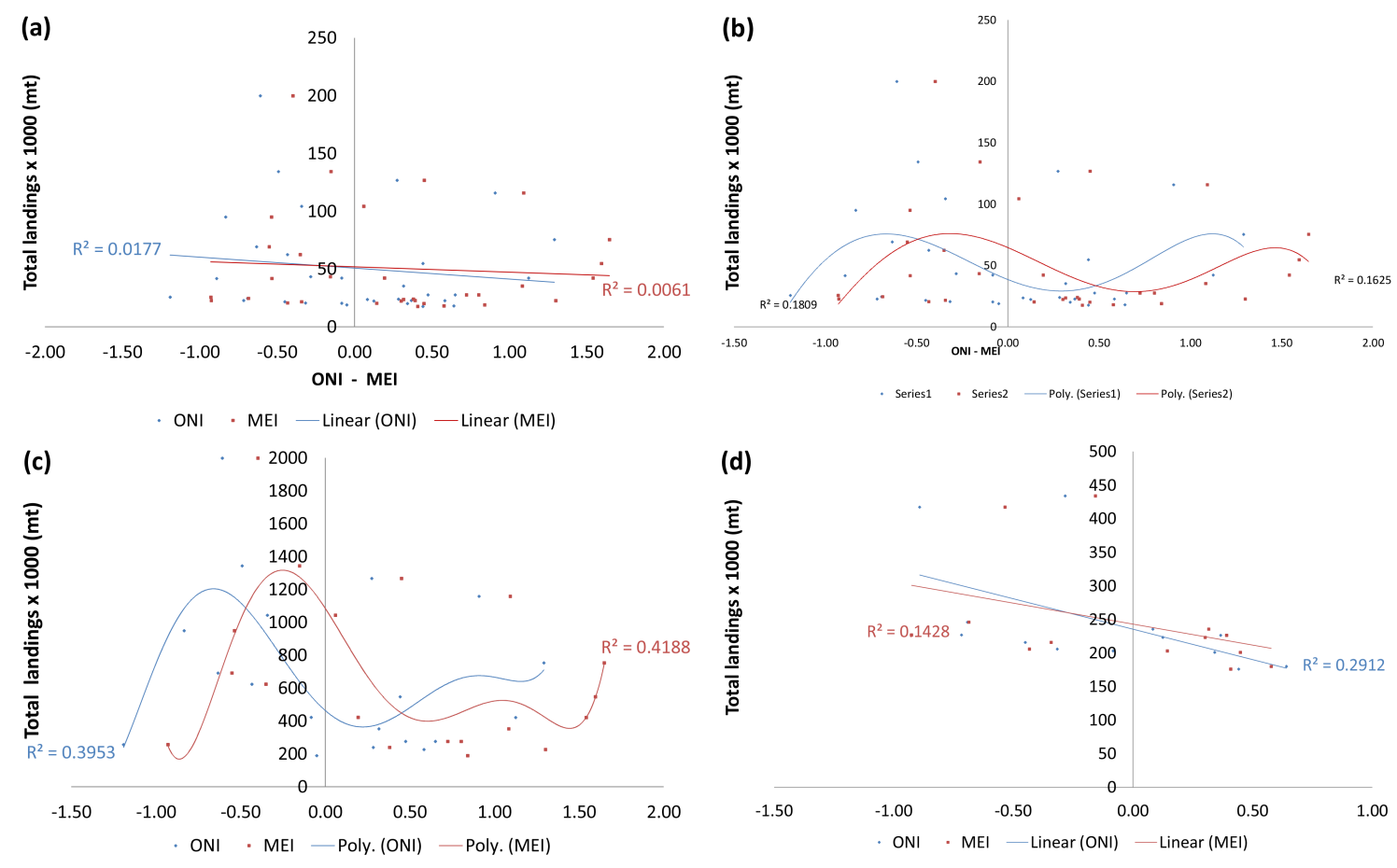

Figure 3. Total landings vs. the ONI and MEI for periods (a) 1981-2012, (b) 1981-2012, $n=5$, (c) 1981-1999, $n=6$, and (d) 2000-2012.

Figure 4 shows regression between landings against ONI and MEI using quarterly data for the variables $\left(\mathrm{Q}_{4}\right)$ of the same year for 1981-2012. Linear regression obtained an $R^{2}$ of 0.299 (MEI) and a 0.237 (ONI) mean that showed about
$24-30 \%$ of the total pelagic fish captured is affected by ONI and MEI, and that there is higher biomass under cold conditions (La Niña and cold PDO); the highest catch occurred around -0.5 . If polynomial regression $(n=3)$ is considered, 

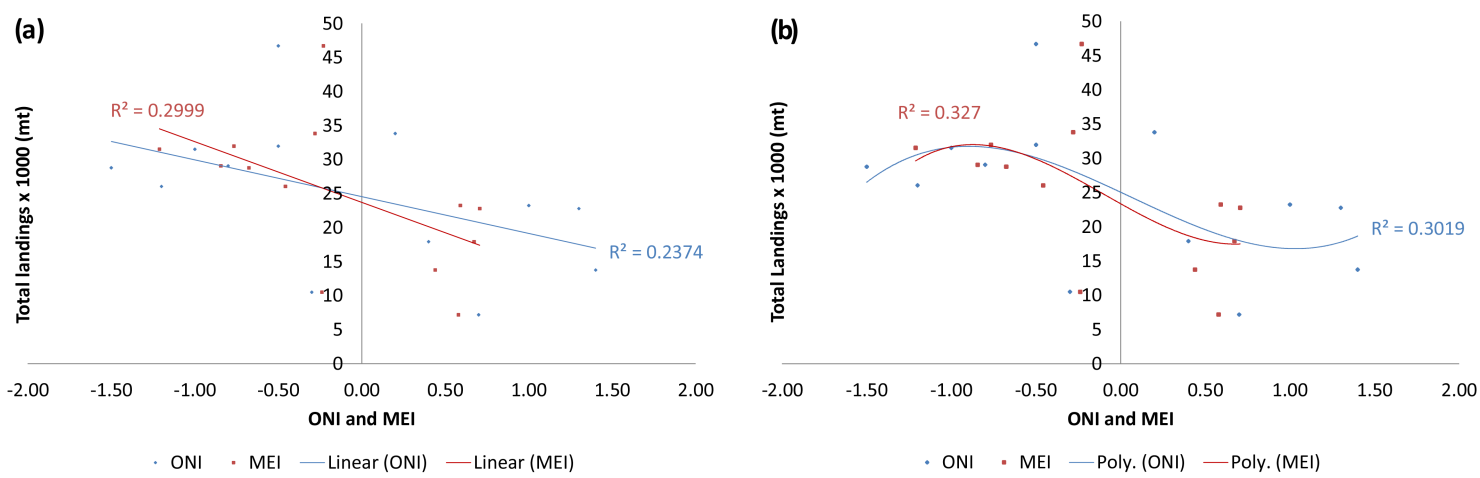

Figure 4. Total landings in $\mathrm{Q}_{4}$ vs. the ONI and MEI (2000-2012). Polynomial regression, $n=3$.

association reaches $30 \%$ for ONI and $33 \%$ for MEI, increasing the degree (n) of the polynomic function, $R^{2}$ did not improve. Total landing using $\mathrm{Q}_{3}, \mathrm{Q}_{2}$ and $\mathrm{Q}_{1}$ did not perform better. Thus, $\mathrm{Q}_{4}$ for landings and the same quarter for MEI and ONI were considered for correlative analysis for each species.

In general terms, total landings of small pelagic fish were affected by as much as $58 \%$ by oceanographic conditions on a nonlinear basis $(n=6)$ from 2000 , but under the influence of linear regression reach ca. 24 and $30 \%$ for the MEI and ONI, respectively. This global analysis demonstrates that time series 1981-2012 needs to be separated into 1981-1999 and 2000-2012 to avoid "noise" from a full hot interdecadal period over the following cold one; the latter is roughly in the middle of its complete period.

\subsection{Round herring (Etrumeus teres)}

Round herring proved to be negatively affected by cold PDO, as there was a noticeable decrement of landings after 2000; thus, the annual landing average during 1981-2000 was $38548 \mathrm{mt}$, whilst for $2000-2012$ it was $2039 \mathrm{mt}$, i.e., a fall of $95 \%$ (Fig. 2). Linear regression analysis (without considering the extraordinary landing in 1981) showed a dependence on the ONI and MEI of 12 and $21 \%$, respectively. $R^{2}$ values of $4.3 \%(n=5)$ and $14.3 \%(n=4)$ are obtained with the polynomial regression, considered poor correlations. Landings for the second period were more associated with the MEI / ONI, denoting that during negative MEI periods $(<0.1)$ its availability is higher but decreases dramatically in an intense cold event or moderately severe hot event (Fig. 5). Correlation with the ONI during moderate or intense La Niña periods shows that round herring availability increases but also eventually falls into a moderate-hot event.

\subsection{Bullet tuna (Auxis spp.)}

Bullet tuna began to be reported in 1998 in increasing volumes, except in 2004 and 2005, during an El Niño event. The correlation of landings vs. MEI (Fig. 5) gave a negative slope $\left(R^{2}=0.149\right)$, indicating that the resource decreases as the index increases. The nonlinear correlation $(n=3)$ results in an $R^{2}$ of 0.367 (Pearson $r=0.606$ ). The linear and nonlinear regression $(n=3)$ was low with ONI, but the slope was the same.

\subsection{Mackerel (Trachurus murphyi)}

Mackerel landings were reported for the first time in 1990, and then continuously until 2002. After that, it is reported only in 2007 and 2009 (19834 mt); the peaks occurred during or after cold periods (1996 and 2000). The regression analysis for the period did not gave $R^{2}$ results higher than 0.10 ; therefore, this species cannot be considered a possible index.

\subsection{Anchovy (Engraulis ringens)}

Ecuador started registering Peruvian anchovy landings (Fig. 6) in 2001 (at the end of the strong La Niña of 2000); by 2001 they peaked up to $71013 \mathrm{mt}$, but immediately after decreased to $11273 \mathrm{mt}$, bouncing back in 2006 with a record value of $76606 \mathrm{mt}$, and then fell again. This behavior is similar to a sine/cosine function or a polynomial $n=4$ with an $R^{2}$ of 0.438 , with a negative slope. Low values obtained from landings during La Niña 2010-2011 could be related to a displacement of the resource towards the open sea, and were not available to be captured by the fishing fleet (which operates near the coast); by contrast, higher catches were reported by Peruvian fishermen in 2011 ( 8.3 million $\mathrm{mt}$, FAO, 2014). MEI had a negative slope for this period (Fig. 6), implying that a lower SST had a higher production of Peruvian anchovies; in 2012 there was an important diminution of 4.7 million mt (FAO, 2014) as a response of a "Modoki" El Niño (Ormaza-González, 2012); also in 2012 the MEI increases from -0.93 (2011) to 0.14 , showing a swift response of anchovy to SST fluctuations.

Annual landings correlated with the MEI and ONI gave $R^{2}$ values for polynomials $(n=4)$ of 0.25 and 0.156 , respectively, denoting a relation to cold and warm events (Fig. 7) 

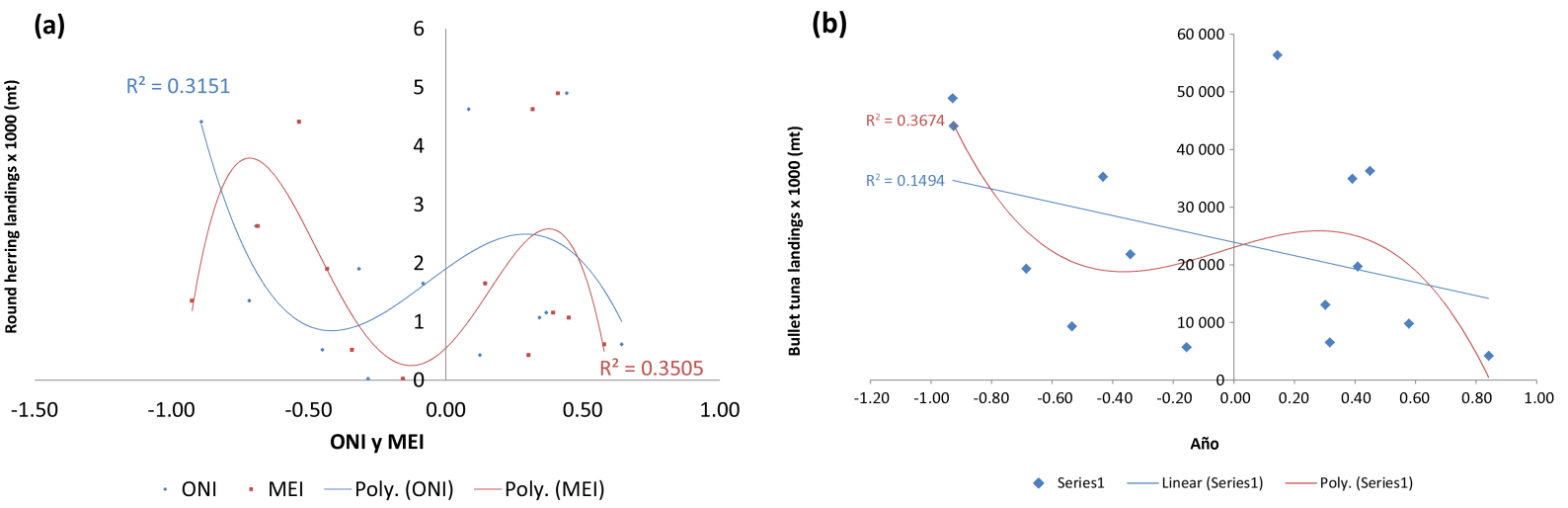

Figure 5. (a) Round herring (1981-2012); polynomial regression $(n=4)$. (b) Bullet tuna (2000-2012) vs. MEI. Polynomial degree $(n=3)$.

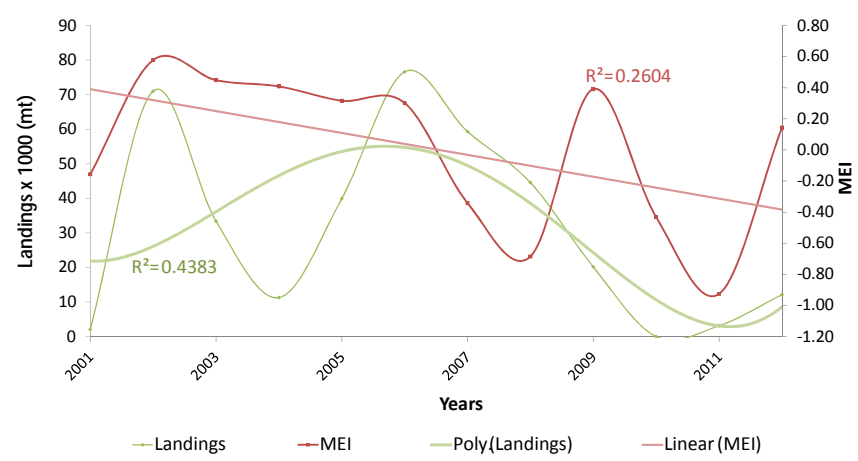

Figure 6. Landings (desembarque) of anchovy (2001-2009), associated with the MEI. Green solid curve $(n=4)$ and the linear regression (straight line).

of between 25 and $16 \%$, in that order. Linear correlation showed a positive slope with an 11 to $8 \%$ association with the indexes, respectively. Quarterly $\left(\mathrm{Q}_{4}\right)$ landings had a linear correlation of 7-9\% (Fig. 7). Anchovy fishing proved to be strongly related to low-frequency fluctuations or cold PDO; during warm periods (1981-1999) it was not reported in Ecuador and began to appear in the cold PDO period. Its tendency during long periods increases to lower SST or cold interdecadal PDO. This species could be considered a fishing index associated with the ONI.

\subsection{South American pilchard (Sardinops sagax)}

In Ecuador, it is reported with important landings from 1981 (perhaps before it was captured, but not registered). In general, it seems to have two periods of 10 years each (19811995 and 1994-2003), with a record landing $>1.2$ million $\mathrm{mt}$ in 1985, but it disappeared or had not been captured since 2006. Figure 8 shows landings in association with the MEI and ONI during the entire period (1981-2006). When $n=1$, $R^{2}$ were lower, at 0.052 (MEI) and $0.058(\mathrm{ONI})$ with a negative slope; this means they decrease towards positive values for both indexes.
When landings were related by quarter $\mathrm{Q}_{4}$ to similar MEI and ONI, the results maintained low $R^{2}$, but when $\mathrm{Q}_{1}$ of the next year was analyzed with $\mathrm{Q}_{4}$ of MEI / ONI of the previous year (Fig. 8), a linear $R^{2}$ of 0.225 (MEI) and 0.109 (ONI) was observed; i.e., landings in the first quarter of the year are going to be attached by up to $22 \%$ of the MEI average from the last quarter. This correlation also indicates that when MEI is higher than -0.5 , there will be low or null captures, thus suggesting South American pilchard is positively associated with La Niña and cold PDO. This exercise indicates that South American pilchard "feels" what happens in El Niño 3-4 with around a month later in $\mathrm{Q}_{1}$ of the following year, and therefore it could be considered a possible predictor.

\subsection{Chub mackerel (Scomber japonicus)}

In 1981, landings of $<0.45$ million $\mathrm{mt}$ were reported, reaching a maximum peak of 0.59 million $\mathrm{mt}$ in 1982 (El Niño event), and then dropped steadily with smooth highs and lows to $25600 \mathrm{mt}$ (1992); then landings went up to an average of $255400 \mathrm{mt}$ till 2009, from there sustaining a median of $60000 \mathrm{mt}$ till 2012 (Fig. 9). Landings are a quasi mirror relation between landings and the MEI-ONI; however, linear and nonlinear correlations gave low $R^{2}$ with both the ONI and the MEI.

\subsection{Chuhueco (Cetengraulis mysticetus)}

Since 1981, landings have averaged $41240 \mathrm{mt} \mathrm{year}^{-1}$, with a minimum (2007) of $1079 \mathrm{mt} \mathrm{year}^{-1}$ and a maximum (1987) of $126420 \mathrm{mt}^{\text {year }}{ }^{-1}$. Total landings for the study period exceeded 1.19 million mt, which represents $8 \%$ of total captures. Figure 10 shows that landing peaks reflect a high MEI and vice versa. In the years 1983, 1987, 1992 and 1997 (El Niño), significant peaks can be noted, whilst during La Niña events notable falls are registered. Linear regression coefficients of landings against the ONI was about 0.16 , whilst for the MEI they were up to 0.200 (Fig. 10), i.e., a $20 \%$ asso- 
(a)

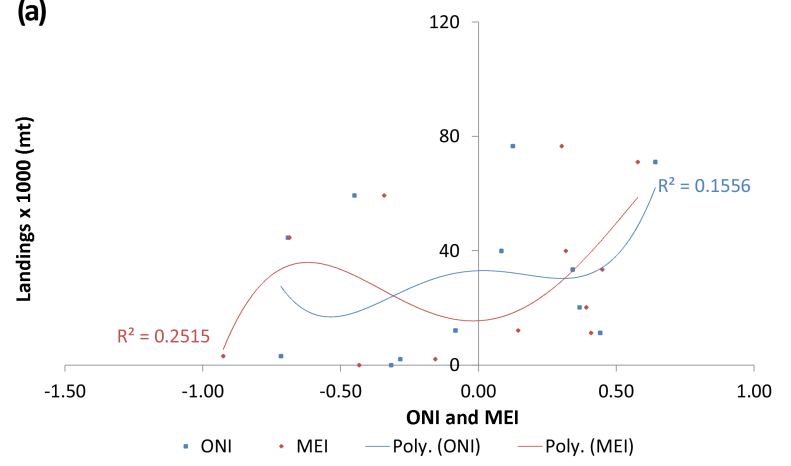

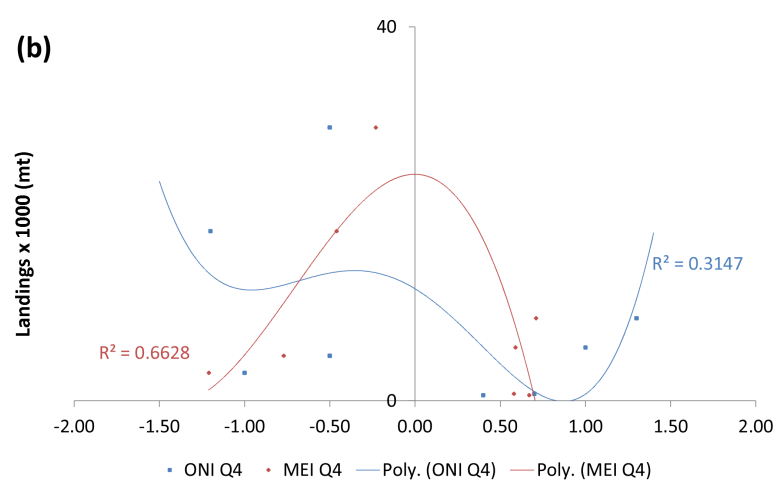

Figure 7. Yearly and $\mathrm{Q}_{4}$ anchovy landings vs. the ONI and MEI (2001-2012), $n=4$. $\mathrm{Q}_{4}$ (T4) vs. MEI $(n=3)$.
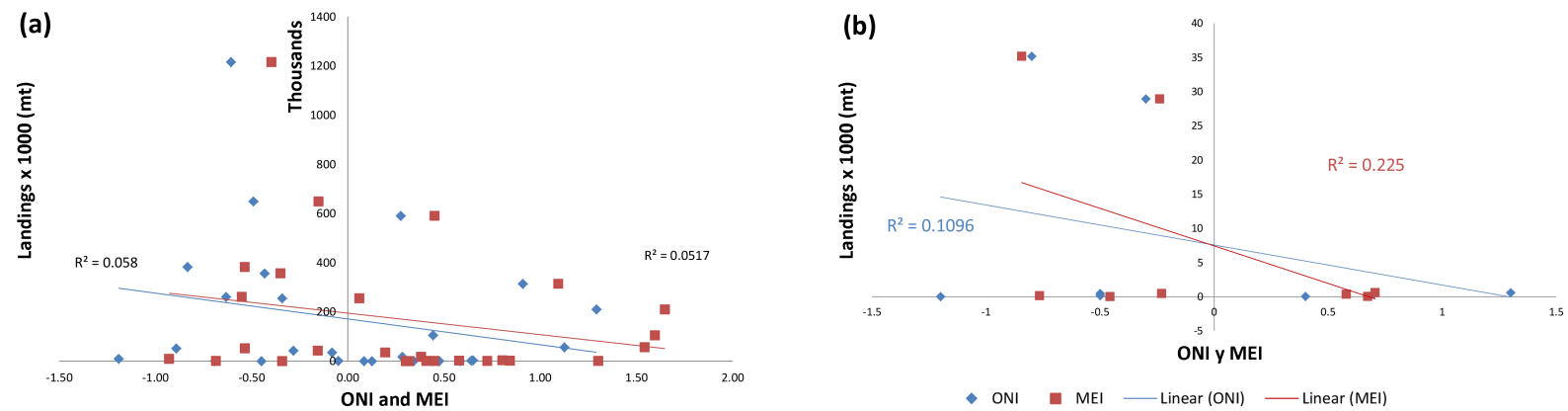

Figure 8. Annual landings of South American pilchard vs. ONI/MEI (1981-2006) and $\mathrm{Q}_{1}$ landings vs. $\mathrm{Q}_{4}$ ONI/MEI (2000-2008).

ciation with a positive slope, indicating that this species is linked to warm events when the highest landings are registered. In the long run, it is affected by the PDOs; from 2000, landings were down to $20000 \mathrm{mt}$.

Separating time series into 1981-1999 and 2000-2012 gave a better $R^{2}(0.16$ to 0.18$)$ for the linear regression, with a positive slope, indicating again that warm periods and El Niño favor the population and availability of fish. For the polynomial functions of $n=5(\mathrm{ONI}), R^{2}=0.522$ $(r=0.722)$ was obtained during the period (1981-1999).

The regression coefficients obtained with the fourth quarter for both variables (Fig. 11) were not that good, as with other species. The slope was slightly negative (ONI) and positive (MEI); $R^{2}=0.272(n=6)$ for ONI, while the linear function for MEI was poor (0.0022). Chuhueco cannot be used as a short-term associated index for El Niño.

\subsection{Pacific thread sardine (Ophistonema $\mathrm{sp.)}$}

This species, as others, registered a continuous fall from 1983 (328 $000 \mathrm{mt})$ to $1992(31000 \mathrm{mt})$; a year later an increase to 69000 is recorded, and then a decrease till 2012, reaching a minimum of $6900 \mathrm{tm}$ in 2003. Figure 12 shows that warmhot events make landings decrease.

Figure 13 displays a poor linear regression for 1981-1999, showing a negative slope; however, for series 2000-2012, $R^{2}$ is 0.242 (Pearson $r=0.492$ ) with a negative slope as well; i.e., in this period up to $24 \%$ of the landings are affected by oceanographic fluctuations. The correlations also indicate that this species is negatively affected by warm-hot events, and the opposite is true for cool-cold ones. The highest association was achieved with a polynomial regression $(n=5)$ that gave an $R^{2}$ of 0.444 ( $\left.r=0.666\right)$.

Correlation using quarters $\left(\mathrm{Q}_{1}, \mathrm{Q}_{2}, \mathrm{Q}_{3}\right)$ and ONI/MEI data gave $R^{2}<0.20$, but with $\mathrm{Q}_{4}$ for the series 2000-2012 (Fig. 14), $R^{2}$ improved to 0.242 (linear regression) and 0.359 (polynomial function, $n=3$ ); i.e., $\mathrm{Q}_{4}$ landings are affected $24-36 \%$ by oceanographic conditions.

The catch effort of the small pelagic fleet was estimated by the trip of the fleet (boats of less than $35 \mathrm{mt}$ ); they fish very close to the coast (1-day travel) with maximum sails of 22 per month. The boats do not have any cooling system capacity. The catch effort per month landing was normalized by the numbers of sails per month. Canales et al. (2013) have estimated that there is overfishing of this species, as the catch effort has continuously decreased from 1983 to 2009 , to a slight increase to the present. Poor correlations $\left(R^{2}<0.001\right)$ of catch effort and MEI / ONI were found. One possible reason for this is that sails are dependent on many other variables completely unassociated with oceanographic conditions. 


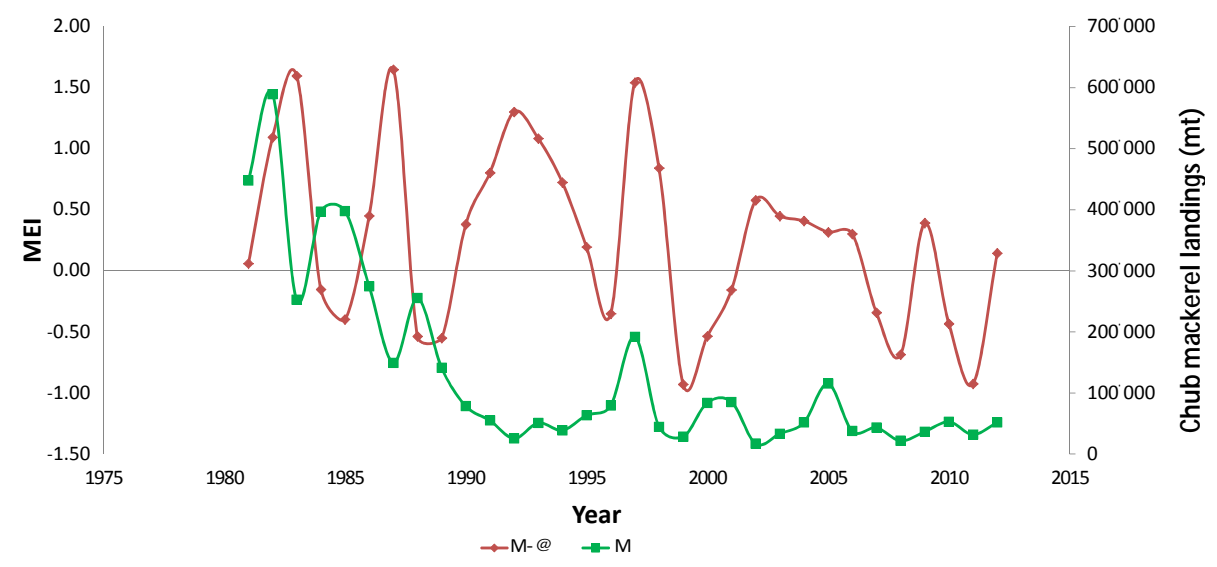

Figure 9. Chub mackerel (macarela) landings (1981-2012) vs. the MEI.

(a)
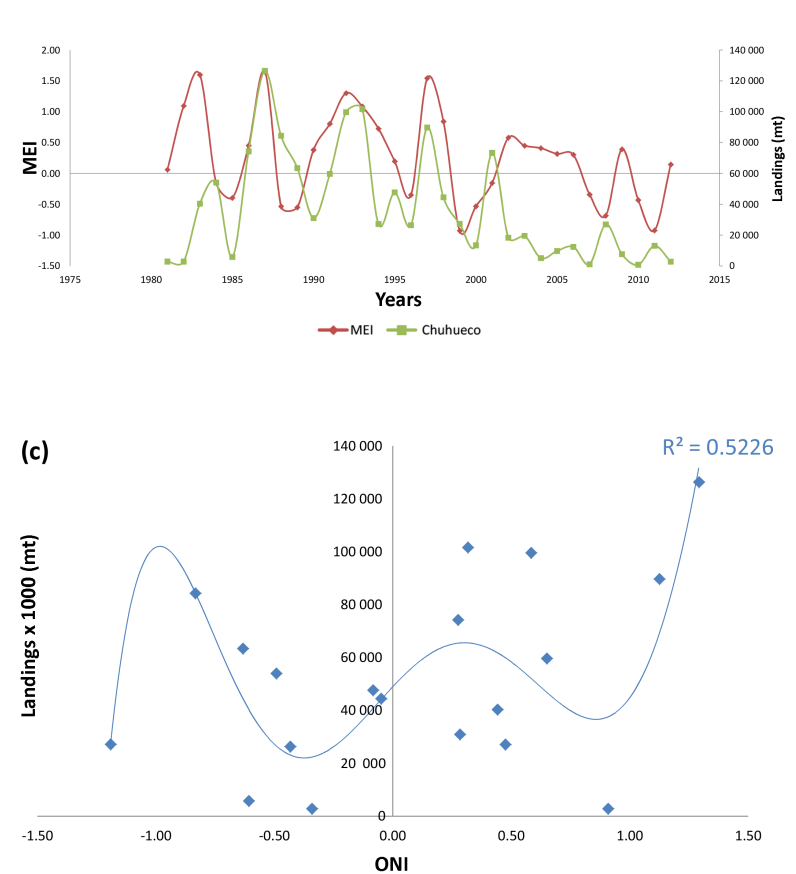

(b)
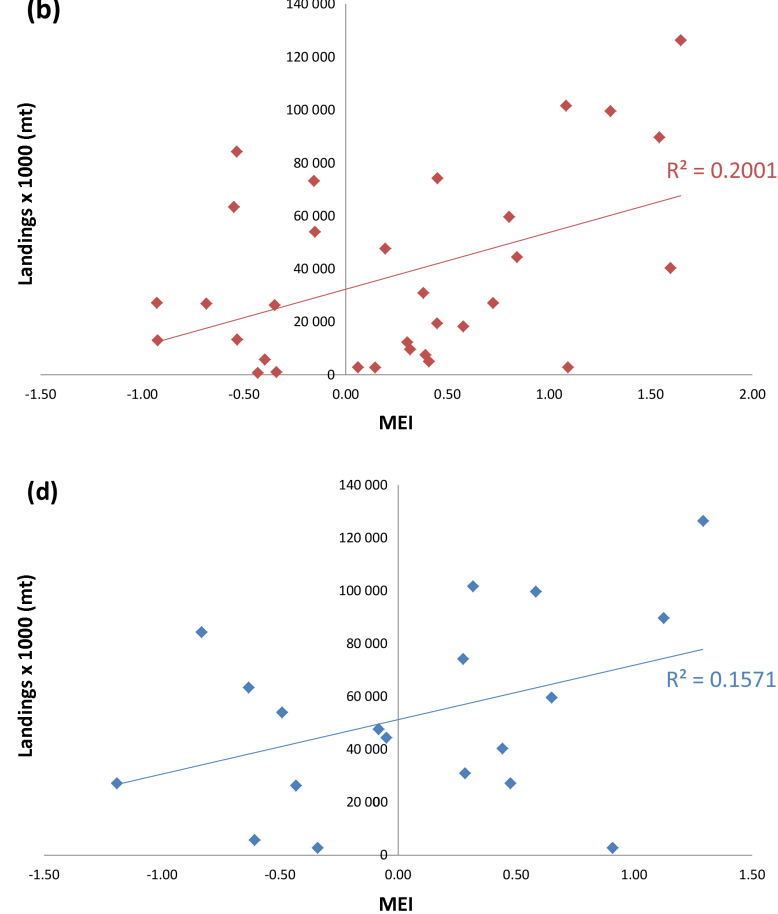

Figure 10. Chuhueco landings (1981-2012) vs. ONI and MEI. (a) Landings vs. MEI, linear correlation landings vs. MEI (b) and ONI (d), and (c) polynomial $(n=6)$.

\section{Discussion and conclusions}

The total landings registered a historical maximum in 1985 after the 1982 strong El Niño. From this point, landings decreased consistently until 1990; then, it is somehow annually kept around $190000 \mathrm{mt}$ (except for peaks for 19951997) till the present. In general terms, fisheries recorded a constant fall in time for total and individual species landings (Fig. 2). The total landings did not show strong correlation (Fig. 3) in the whole time series (1981-2012), especially with high-frequency events (El Niño), but they were stronger during the period 2000-2012 (14-29\%,), when La Niña events prevailed. On the other hand, total landings did correlate better with PDOs; this sort of synchrony between landings of pelagic species and oceanographic conditions has been reported by, e.g., Chávez et al. (2003), Lehodey et al. (2006), and Ormaza-González et al. (2014b). The weak correlation with high-frequency events is because landings are affected by numerous factors, from environmental conditions to lacking/deficient economical resources for fleet operation, high coastal variability, maintenance of vessels, skipper skillfulness, legal bans, and even luck or reasons beyond 


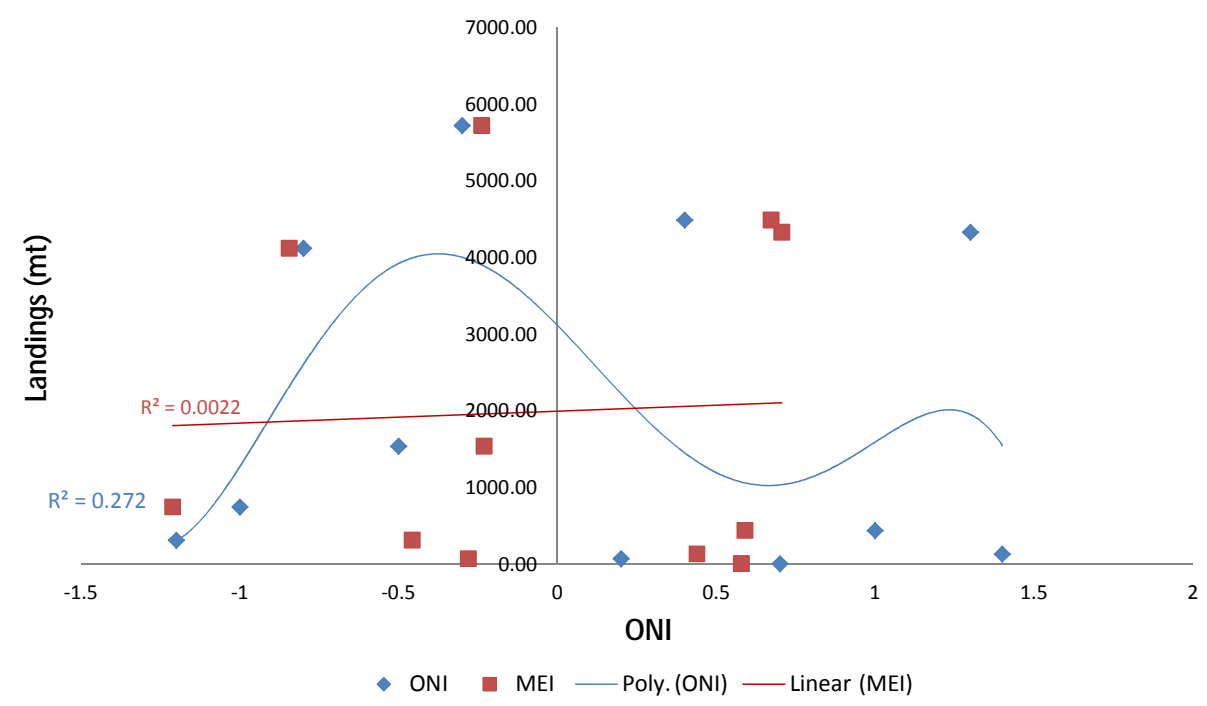

Figure 11. Chuhueco $\mathrm{Q}_{4}$ (trimester, October-December) vs. the ONI ( $\left.n=5\right)$ and MEI Q 4 (October-December), $2000-2012$.

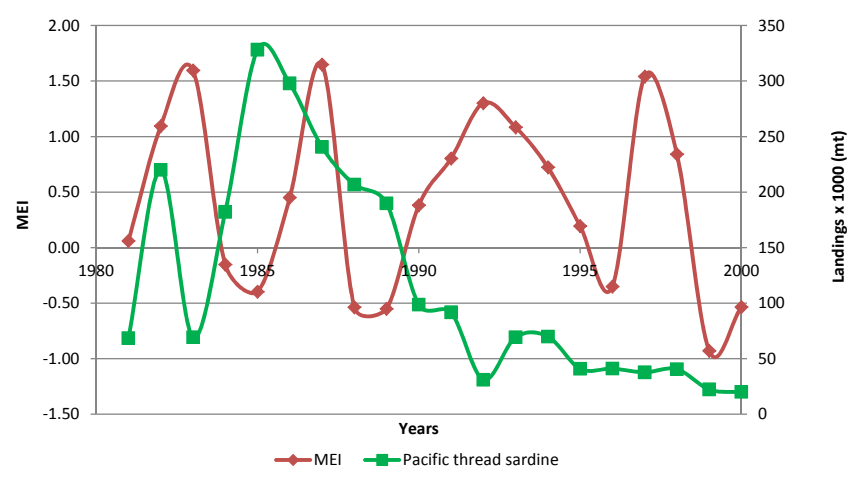

Figure 12. Landings (mt) of Pacific thread sardine (pinchagua) and its relationship with MEI in time.

understanding, and, on top of that, sampling, which could be flawed by different circumstances, like a deficient skipper $\log$ book, absence of samplers, and unsuitable conditions for sampling.

Analysis of yearly landings per species could be used as a sort of predictor knowing that the association with oceanographic conditions could be around $24 \%$ on a linear basis; this sort of correlation $\left(R^{2}\right)$ could be considered high in view of what was said above. Using trimestral averages, the $\mathrm{Q}_{4}$ (October-December) analysis especially showed an improved $R^{2}$ on a linear regression basis, especially the South American pilchard and pacific thread herring up somewhere around $22 \%$. In all cases when nonlinear regression was used, the $R^{2}$ increased notably, particularly when using $\mathrm{Q}_{4}$ analysis. The species affected positively by El Niño were basically chuchueco and bullet tuna, and, negatively, round herring, anchovy, pacific thread herring and South American pilchard, and the species that did not show good enough cor- relations with the MEI and ONI were Chilean jack mackerel and chub mackerel. Preliminary exercises using biological (length and weight) data for the Pacific thread herring showed almost double association up to $46 \%$; i.e., the weights of female individuals are affected directly up to $46 \%$ by the MEI.

Under neutral conditions (MEI / ONI $>-0.5$ and $<0.5$ ) there is an important dispersion of fish landings; however, at extreme values of MEI / ONI $(<-1.0$ and $>1.0)$, the nonlinear ( $n=3$ to 6 ) analysis showed that landings tend to importantly decrease; the nonlinear $(n>3)$ statistical analysis gave $R^{2}$ values of between 0.4 and 0.8 , showing the high association of landing and oceanographic events.

On the other hand, the negative slopes found in longterm behavior of landings clearly indicated that during cold periods (e.g., 2000-2025/2030), there should be smaller pelagic species (except chuhueco) biomass in the water column, which in warm periods should be less. During cold decadal periods, upwelling processes prevail as the undercurrent water mass increases in volume as southern trade winds take the central-eastern Pacific surface waters off to the central-western Pacific, provoking intense upwelling of the Humboldt and Cromwell currents. Thus, there is input of inorganic nutrients, thereby increasing photosynthesis at the surface; then, phytoplankton biomass (the base of the trophic chain) will increase, so species at higher trophics will have more energy available. The opposite occurs under warm PDO. Under the latter circumstance small or big pelagic species will have to redistribute themselves, looking for colder and biologically richer waters, as warm waters have relatively lower dissolved oxygen, which is less soluble at higher temperatures, and there is an absence of, or weak, photosynthesis; thus, at the end fish become less available to be captured. 

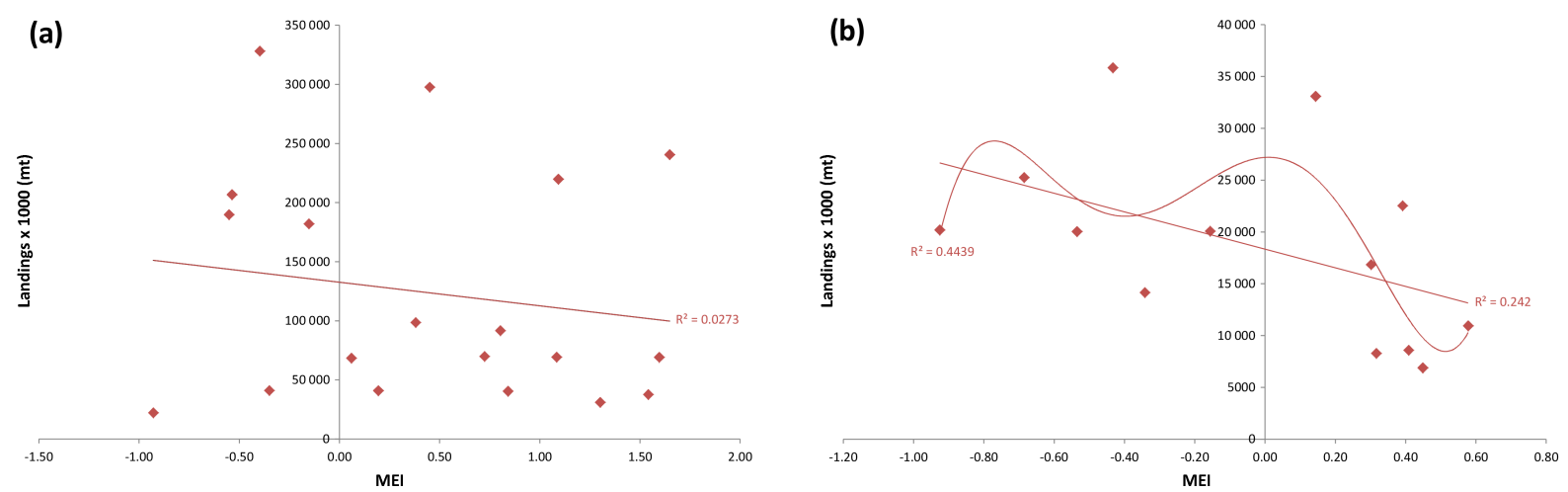

Figure 13. Correlation of pinchagua landings and MEI in the periods (a) 1981-1999 and (b) 2000-2012. Polynomial ( $n=5$ ).

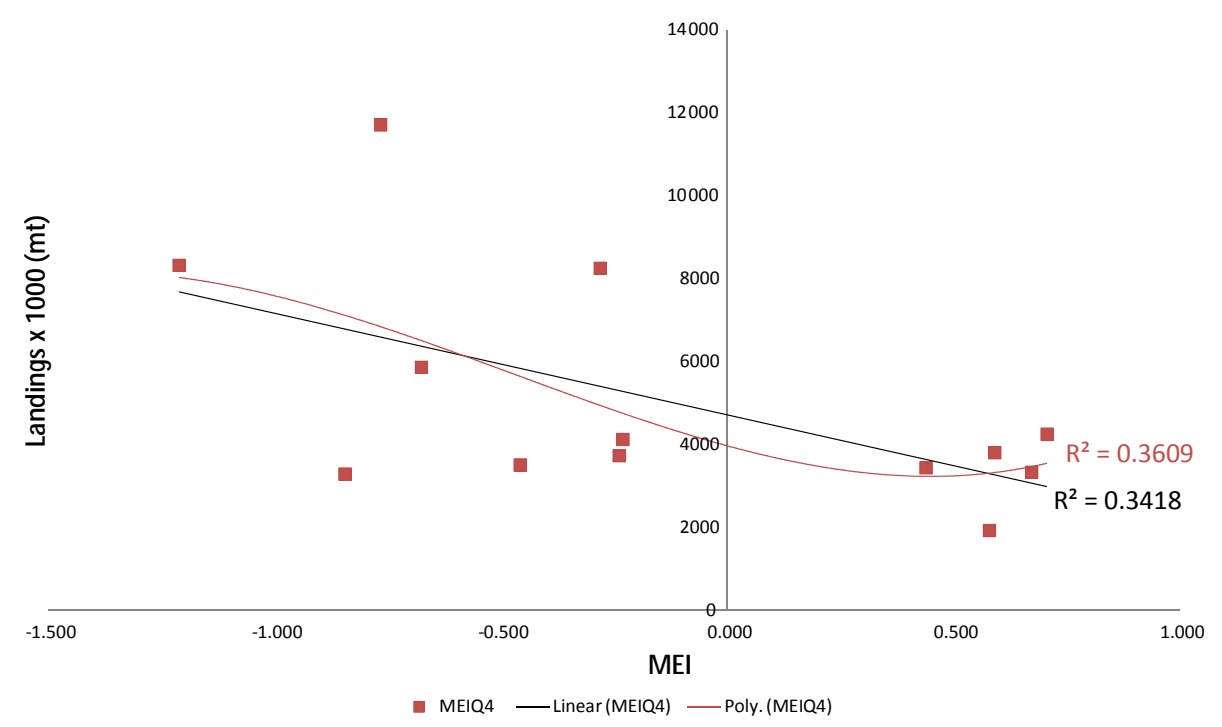

Figure 14. Q4 landings of pinchagua vs. MEI (2000-2012).

Even though landings are not the best parameter to be correlated with oceanographic conditions, it was found that there is a consistent $20-30 \%$ of direct influence on linear regression analysis. These results show that management of commercial fish must be analyzed in the light of oceanographic conditions, those occurring over short (El Niño) as well as longer time periods (PDO). Slight oceanographic fluctuations may particularly impact the maximum sustainable yield (MSY), especially when managers are working with only half of the carrying capacity of the fish population (K/2, Ormaza-González et al., 2014b). The analysis presented provides a first effort in predicting the impact of oceanographic conditions on fishing and vice versa over short and long intervals of time.

Finally, results would suggest that the South American pilchard and Pacific thread herring could be considered good species to use as predictors of El Niño in region 1-2 (Ecuador), especially when average $\mathrm{Q}_{4} \mathrm{MEI} / \mathrm{ONI}$ is used against the next trimester $\mathrm{Q}_{1}$ landings. All species were prone to have lower landings and/or fishing availability during strong-extreme events (ONI/MEI, $>1.0$ and $<-1.0$ ), and were also shown to be affected by the PDO. In the long term, landings decreased under warm PDO and vice versa, and therefore PDO fluctuations could be used to help manage these fisheries and for the industry for long-term planning.

Future work for more informed correlation work could include using length, weight, and diet content (to determine medium trophic level); working with data on a quarter or monthly basis would give perhaps better and higher correlation coefficients, and much clearer information that would help managers to improve their assessment tools. 


\section{Data availability}

Oceanographic El Niño Index (ONI) data are available at: http://www.cpc.ncep.noaa.gov/products/ analysis_monitoring/ensostuff/ensoyears.shtml. Multivariate ENSO Index (MEI) data are available at: http://www.esrl.noaa.gov/psd/enso/mei.ext/table.ext.html.

Data one pelagic fish landings are available on request to: Mario Hurtado (mhurtadodominguez@gmail.com), Manuel Peralta (mperalta72@gmail.com), and Viviana Jurado (vjurado@institutopesca.gob.ec).

Author contributions. Franklin Isaac Ormaza-González led and was in charge of the whole project. He searched for funds. He conceptualized the hypothesis, researched the literature, designed the material and methods, and wrote the paper in all its stages. Alejandra Mora-Cervetto and Raquel María Bermúdez-Martínez downloaded data on oceanographic indexes and small pelagic fish landings, organized data, information and literature research, researched statistical methods, and reviewed many drafts. Mario Armando Hurtado-Domínguez, Manuel Raúl Peralta-Bravo, and Viviana Mariuxi Jurado-Maldonado were keepers and researchers of the pelagic fish data and organized information and researched stocks, catch per unit efforts, fleet, and vernacular and scientific names.

Acknowledgements. Project SENACYT-INAMHI-INP, "Explotación y planeamiento de metodología para el desarrollo del indice pesquero-proyecto enos del INAMHI" (CDC-INAMHI130-2013; the Escuela Superior Politécnica del Litoral (ESPOL) leading institution. Universidad Espirítu Santo del Ecuador allowed research time to F. I. Ormaza-González to write part of the paper. ESPOL provided time (to F. I. Ormaza-González) to finish up the paper. Carlos Naranjo, Raul Mejía and Maritza Aguirre (INAMHI), who provided all assistance to fulfill all project requirements. José Luis Santos (ESPOL), scientific administrator of the project. Special thanks to the whole group of scientists and technicians (INP, INAMHI) that helped immediately when requested. P. J. Statham, University of Southampton, generously provided valuable comments and improved the language. Special thanks to Daphne Vera-Mosquera for her detailed attention.

Edited by: R. Martínez

Reviewed by: M. P. Cornejo Rodriguez and one anonymous referee

\section{References}

Aburto-Oropeza, O., Sala, E., Paredes, G., Mendoza, A., and Ballesteros, E.: Predictability of reef fish recruitment in a highly variable nursery habitat, Ecology, 88, 2220-2228, 2007.

Barber, R. T. and Chávez, F. P.: Biological consequences of El Niño, Science, 222, 1203-1210, 1983.

Barber, R. T. and Chávez, F. P.: Ocean variability in relation to living resources during the 1982-83 El Niño, Nature, 319, 279-285, 1986.

Cahuin, S. M., Cubillos, L. A., Escribano, R., Blanco, J. L., Niquen, M., and Serra, R.: Sensitivity of recruitment rates anchovy (Engraulis ringens) to environmental changes in Southern Peru-Northern Chile, Environ. Development, 7, 88-101, doi:10.1016/j.envdev.2013.03.004, 2013.

Canales, C., Peralta, M., and Jurado, V.: Evaluación de la población de pinchagua (Opisthonema spp) en el Ecuador y perspectivas de explotación, Internal Report, Instituto Nacional de Pesca Ecuador, 2013.

Chávez, F. P., Ryan, J., Lluch-Cota, S. E., and Ñiquen, M.: From Anchovies to Sardines and Back: Multidecadal Change in the Pacific Ocean, Science, 299, 217-21, doi:10.1126/science.1075880, 2003.

Clarke, A. J.: An introduction to the dynamics of El Niño y the Southern Oscillation, Academy press, 301 pp., 2008.

D’Croz, L., Del Rosario, J. B., and Gómez J. A.: Upwelling and phytoplankton in the Bay of Panama, Rev. Biol. Trop., 39, 233241, 1991.

De la Cuadra, T.: Comportamiento de las capturas de peces pelágicos pequeños en relación con la temperatura durante el 2004, Rev. Ciencias del Mar y Limnología, 4, 1-8, 2010.

Dioses, T.: Influencia del fenómeno El Niño 1982-83 en peso total individual de los peces pelágicos: sardina, jurel y caballa, IMARPE-Peru, 1983.

FOA: The State of World Fisheries and Aquaculture: Opportunities and challenges, FAO 2014, 243 pp., available at: http://www.fao. org/3/a-i3720e.pdf, 2014.

Gaxiola-Castro, G., Lavaniegos, B. E., Martínez, A., Castro, R., and Espinosa-Carreón, T. L.: Pelagic ecosystem response to climate variability in the Pacific Ocean off Baja California, in: Climate Change and Variability, edited by: Simrad, S. W. and Austin, M. E., 163-182, doi:10.5772/9807, 2010.

Gómez, F., Montecinos, A., Hormazabal, S., Cubillos, L. A., Correa-Ramirez, M., and Chávez, F. P.: Impact of spring upwelling variability off southern-central Chile on common sardine (Strangomera bentincki) recruitment, Fish. Oceanogr., 21, 405414, 2012.

Hsieh, C. H., Kim, H. J., Watson, W., Di Lorenzo, E., and Sugihara, G.: Climate-driven changes in abundance and distribution of larvae of oceanic fishes in the southern California region, Glob. Change Biol., 15, 2137-2152, 2009.

Iriarte, J. L. and Gonzalez, H. E.: Phytoplankton size structure during and after the 1997/98 El Niño in a coastal upwelling area of the northern Humboldt Current System, Mar. Ecol., 269, 83-90, 2004.

Khider, D., Stott, L. D., Emile-Geay, J., Thunell, R., and Hammond, D. E.: Assessing El Niño Southern Oscillation variability during the past millennium, Paleoceanography, 26, PA3222, doi:10.1029/2011PA002139, 2001. 
Lavaniegos, B. E. and Ohman, M. D.: Long-term changes in pelagic tunicates of the California Current, Deep-Sea Res. Pt. II, 50, 2473-2498, 2003.

Lehodey, P.: Climate and fisheries: an insight from the central Pacific Ocean, in: Marine Ecosystems and Climate Variation: the North Atlantic, Oxford University Press, Oxford, 137-146, 2004.

Lehodey, P., Bertignac, M., Hampton, J., Lewis, A., and Picaut, J.: El Niño southern oscillation and tuna in the western Pacific, Nature, 389, 715-718, 1997.

Lehodey, P., Andre, J. M., Bertignac, M., Hampton, J., Stoens, A., Menkes, C., Memery, L., and Grima, N.: Predicting skipjack tuna forage distributions in the equatorial Pacific using a coupled dynamical bio-geochemical model, Fish. Oceanogr., 7, 317-325, 1998.

Lehodey, P., Chai, F., and Hampton, J.: Modelling climaterelated variability of tuna populations from a coupled oceanbiogeochemical-populations dynamics model, Fish. Oceanogr., 12, 483-494, 2003.

Lehodey, P., Alheit, J., Barange, M., Baumgartner, T., Beaugrand, G., Fromentin, J. M., Hare, S. R., Ottersen, G., Perry, R. I., Roy, C., van der Lingen, D., and Werner, F.: Climate variability, fish and fisheries, J. Climate, 19, 5009-5030, 2006.

Mantua, N. J. and Hare, S. R.: The Pacific decadal oscillation, J. Oceanogr., 58, 35-44, 2002.

Mantua, N. J., Hare, S. R., Zhang, Y., Wallace, J. M., and Francis, R. C.: A Pacific interdecadal climate oscillation with impacts on salmon production, B. Am. Meteorol. Soc., 78, 1069-1079, 1997.

McPhaden, M. J.: TOGA-TAO and the 1991-93 El Niño-Southern Oscillation Event, Oceanography, 6, 36-44, 1993.

McPhaden, M. J.: Genesis and Evolution of the 1997-98 El Niño, Science, 283, 950-954, 1999.

Null, J.: El Niño and La Niña Years and Intensities Based on Oceanic Niño Index (ONI), Golden Gate Weather Services, available at: http://ggweather.com/enso/oni.htm, 2013.

Niquen, M. and Bouchon, M.: Impact of El Niño events on pelagic fisheries in Peruvian waters, Deep-Sea Res. Pt. II, 51, 563-574, 2004.

Ormaza-González, F. I.: Un Niño en el Pacífico Central en un período interdecadal frío?, Ecuador Pesquero, Pub. por Cámara de Pesquería del Ecuador, 63, 16 pp., 2012.

Ormaza-González, F. I., Mora-Cervetto, A., and BermúdezMartínez, R.: Consultoría para explotación y planeamiento de metodología para el desarrollo del índice pesquero-proyecto ENOS del INAMHI, Reporte interno INAMHI-Ecuador, 210 pp., 2014a.
Ormaza-González, F. I., Mora-Cervetto, A., Bermúdez-Martínez, R.: Relationships between tuna catch and variable frequency oceanographic conditions, III International Conference on ENSO, Guayaquil, Ecuador, 12-14 November, 2014b.

Rodríguez-Sánchez, R., Lluch-Belda, D., Villalobos, R., and Ortega-García, S.: Large-scale long-term variability of small pelagic fish in the California Current System, Spatial Processes and Management of Fish Populations, University of Alaska/Alaska Sea Grant, Fairbanks, 447-462, 2001.

Sánchez de Benites, G., Álamo, A., and Fuentes, H.: Alteraciones en la dieta alimentaria de algunos peces comerciales por efecto del fenómeno El Niño, IMARPE-Peru, 1983.

Sánchez-Velasco, L., Shirasago, B., Cisneros-Mata, M. A., and Avalos-García, C.: Spatial distribution of small pelagic fish larvae in the Gulf of California and its relation to the El Niño 19971998, J. Plankton Res., 22, 1611-1618, 2000.

Sievers, H. and Vega, S.: Respuesta físico-química de la bahía de Valparaíso a la surgencia generada en punta Curaumilla y al fenómeno El Niño, Revista de Biología Marina y Oceanografía, 35, 153-168, 2000.

Smith, T. M., Reynolds, R. W., Peterson, T. C., and Lawrimore, J.: Improvements NOAAs Historical Merged Land-Ocean Temp Analysis (1880-2006), J. Climate, 21, 2283-2296, 2008.

Trenberth, K. E.: The definition of El Niño, B. Am. Meteorol. Soc., 78, 2771-2777, 1997.

Wirtky, K.: Corrientes superficiales del Océano Pacífico Tropical, Boletín de la Comisión Interamericana del Atún Tropical, 9, 279-304, 1965.

Wolter, K. and Timlin, M. S.: Measuring the strength of ENSO events: How does 1997/98 rank?, Weather, 53, 315-332, 1998.

Wolter, K. and Timlin, M. S.: El Niño/Southern Oscillation behaviour since 1871 as diagnosed in an extended multivariate ENSO index (MEI.ext), Int. J. Climatol., 31, 1074-1087, doi:10.1002/joc.2336, 2011.

Yáñez, E., Hormazábal, S., Silva, C., Montecinos, A., Barbieri, M. A., Valdenegro, A., and Gómez, F.: Coupling between the environment and the pelagic resources exploited off northern Chile: ecosystem indicators and a conceptual model, Lat. Am. J. Aquat. Res., 36, 159-181, 2008. 